\title{
Preparation of Enantiopure Norbornane Ligands Bearing Both (2S,3S)- Bis(phosphinomethyl) and 7-syn-Oxygen Functional Groups and an Application to Rhodium-Catalyzed Asymmetric Hydrogenation
}

\author{
Toshiaki Morimoto, * Akira Yamazaki, and Kazuo Achiwa \\ School of Pharmaceutical Sciences, University of Shizuoka; 52-1 Yada, Shizuoka 422-8526, Japan. \\ Received June 18, 2004; accepted August 23, 2004
}

\begin{abstract}
Enantiopure bicyclo[2.2.1]heptane derivatives having both $(2 S, 3 S)$-bis[(diphenylphosphino)methyl] and 7$s y n$-oxygen functional groups were synthesized by using diastereoselective Diels-Alder reaction of di-(1R)-menthyl fumarate and 5-trimethylsilylcyclopentadiene followed by silver-promoted stereospecific frame rearrangement of a bromolactone intermediate. Rhodium-catalyzed asymmetric hydrogenations were carried out using the diphosphines as a chiral ligand.
\end{abstract}

Key words chiral norbornane; diphosphine ligand; asymmetric hydrogenation; diastereoselective Diels-Alder reaction; stereospecific rearrangement; rhodium

Development of efficient methods for the practical enantioselective synthesis of chiral compounds has been one of the most important subjects in synthetic organic chemistry. ${ }^{1)}$ Many kinds of enantioselective syntheses employing various catalysts such as metal complexes coordinated with chiral ligands have been reported for more than three decades, $\left.{ }^{1-6}\right)$ and several optically pure compounds prepared by enantioselective synthesis with the chiral catalysts are now commercially available (e.g. optically pure $\alpha$-amino acids or alcohols by using asymmetric hydrogenation with $\mathrm{Rh}$ - or $\mathrm{Ru}$-chiral phosphine catalysts ${ }^{3-5)}$; L-menthol by using Rh-BINAP-catalyzed asymmetric isomerization of an allylamine $e^{4)}$ ) and are used as chiral pools or auxiliaries for enantioselective syntheses. For the development of efficient chiral metal complex catalysts, the most significant strategy is based on the preparation of new useful chiral ligands. Various types of di- or mono-functionalized chiral ligands have been developed; for example, di- and mono-phosphines (P,P- or P-type), aminophosphines ( $\mathrm{P}, \mathrm{N}$-type), diamine and amine (N,N- or N-type), etc. On the other hand, tri- or multi-functionalized ligands are much rarer. We previously reported in a preliminary communication the preparation of chiral norbornane derivatives bearing both diphosphine moieties and another hetero functional group. ${ }^{7)}$ In this article we describe in detail the synthesis of enantiomerically pure norbornane derivatives by employing both highly diastereoselective Diels-Alder reaction and stereospecific frame rearrangement (Wagner-Meerwein type rearrangement) as the key steps, and an application to rhodium-catalyzed asymmetric hydrogenation.

\section{Results and Discussion}

The synthetic route to several optically pure norbornane derivatives bearing $(2 S)$ - and $(3 S)$-substituents and an oxygen functional group at the 7-syn position is described in Chart 1. Yamamoto and co-workers reported an efficient Diels-Alder reaction of cyclopentadiene with an optically pure dimenthyl fumarate for the preparation of optically active norbornene derivatives. ${ }^{8)}$ According to Yamamoto's and Fleming's procedures, ${ }^{8-10)}$ the diastereoselective Diels-Alder reaction of 5trimethylsilylcyclopentadiene 1 with di- $(1 R)$-menthyl fumarate 2 was carried out in the presence of diethylaluminun chloride in toluene at $-78^{\circ} \mathrm{C}$ to yield the corresponding
$(2 S, 3 S)$-norbornene-dicarboxylic acid di-(1R)-menthyl ester 3 bearing a trimethylsilyl group at the 7-exo position in a quantitative yield with a diastereomeric excess of $97 \%$. A single recrystallization from ethanol gave optically pure di$(1 R)$-menthyl ester 3 . Halolactonization of the norbornene diester 3 was carried out with bromine to give a bromolactone 4 (97\%) with selective participation of the carbonyl group of the 2-endo ester. The bromolactone 4 was allowed to rearrange stereospecifically with silver nitrate in methanol according to Fleming's procedure. ${ }^{910)}$ The corresponding $(2 S, 3 S)$-norbornene dicarboxylate $\mathbf{5}$ having a 7-syn hydroxyl group was obtained in $88 \%$ yield. The mechanism of the stereospecific frame rearrangement (Wagner-Meerwein type rearrangement) of $\mathbf{4}$ is depicted in Chart 2. A silver cation extracts the bromo atom as an anion, forming a frame-rearranged carbocation intermediate $\mathbf{1 5}$ which is stabilized by a $\sigma_{\mathrm{C}-\mathrm{Si}}-\pi$ conjugate effect of the silyl atom at the $\beta$-position. Elimination of the silyl group as a cation forms a rearranged norbornene lactone intermediate $\mathbf{1 6}$, which has a strained structure and is attacked by methanol, resulting in the formation of norbornene-diester 5 having a 7-syn hydroxyl group stereospecifically. It was known that the silver-promoted frame rearrangement could not be induced in the absence of the 7-silyl group in a methyl ester analog of $4 .{ }^{9,10)}$ The hydroxyl group of $\mathbf{5}$ was protected with chloromethyl methyl ether in the presence of ethyldiisopropylamine, yielding the corresponding methoxymethyl (MOM) ether 6 in 99\% yield. Reduction of the ester groups with lithium aluminum hydride (LAH) gave 2,3-dimethanol 7 (88\%), and subsequent hydrogenation of the olefinic bond with Pd on carbon gave a norbornane-2,3-dimethanol 8 in $92 \%$ yield. Mesylation of the diol 8 was carried out with methanesulfonyl (mesyl) chloride in pyridine at $-35^{\circ} \mathrm{C}$ to afford the dimesylate 9 in $91 \%$ yield. Phosphination of 9 with lithium diphenylphosphide, which was prepared in situ from diphenylphosphine and $n$ butyllithium in tetrahydrofuran (THF) at $-35^{\circ} \mathrm{C}$, gave the diphosphino compound $\mathbf{1 0}$ in $87 \%$ yield. The MOM group of 10 was removed by treatment with trifluoroacetic acid, and the corresponding diphosphine 7-syn alcohol 11 was obtained in $74 \%$ yield. $(2 S, 3 S)$-Norbornane diphosphine $\mathbf{1 4}$ bearing no hetero functional group at the 7-position was also prepared by phosphination of $(2 S, 3 S)$-norbornanedimethanol 


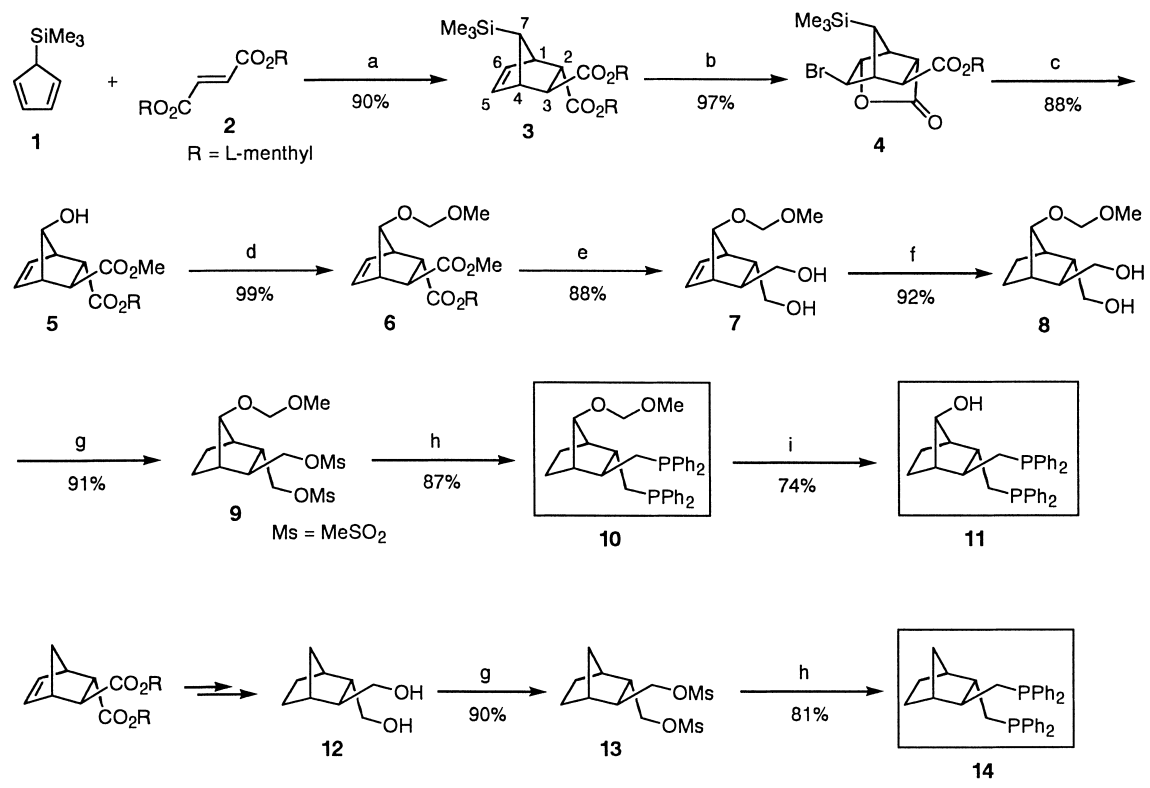

Reagents: (a) $\mathrm{Et}_{2} \mathrm{AlCl}$, toluene; (b) $\mathrm{Br}_{2}, \mathrm{CH}_{2} \mathrm{Cl}_{2}$; (c) $\mathrm{AgNO}_{3}, \mathrm{MeOH}$; (d) $\mathrm{ClCH}_{2} \mathrm{OMe}, i-\mathrm{Pr}_{2} \mathrm{EtN}, \mathrm{CH}_{2} \mathrm{Cl}_{2}$; (e) $\mathrm{LiAlH}_{4}, \mathrm{THF}$; (f) $\mathrm{Pd} / \mathrm{C}, \mathrm{H}$, EtOH; (g) MsCl, pyridine; (h) $\mathrm{LiPPh}_{2}, \mathrm{THF}$; (i) (1) $\mathrm{CF}_{3} \mathrm{CO}_{2} \mathrm{H}, \mathrm{CH}_{2} \mathrm{Cl}_{2}$, (2) $\mathrm{NaOH}, \mathrm{THF}$.

Chart 1. Synthesis of (2S,3S)-Bis[(diphenylphosphino)methyl]bicyclo[2.2.1]heptane Derivatives Having 7-syn-Oxy-Functional Groups

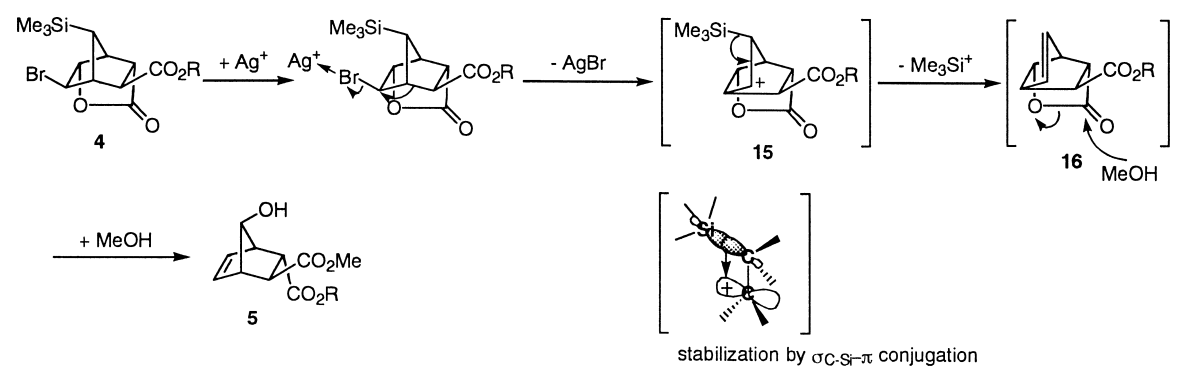

Chart 2. Mechanism of Silver Cation-Promoted Frame Rearrangement of Norbornane Bromolactone 4

dimesylate 13 which was prepared similarly via a synthetic intermediate reported by Yamamoto et $a l .{ }^{8)}$

By using two representative norbornane diphosphines $\mathbf{1 0}$ and $\mathbf{1 4}$ as chiral ligands, preliminary asymmetric hydrogenation of functionallized olefins, itaconic acid and (Z)- $\alpha$ acetamidocinnamic acid, was carried out with a cationic rhodium complex catalyst. The results are summarized in Table 1 . In the presence of $0.1 \mathrm{~mol} \%$ of the rhodium complexes prepared in situ by mixing bis(norbornadiene)rhodium(I) perchlorate $\left[\left[\mathrm{Rh}(\mathrm{nbd})_{2}\right]^{+} \mathrm{ClO}_{4}^{-}\right]$with $\mathbf{1 0}$ and 14, the hydrogenation of itaconic acid proceeded smoothly under 1 atm of hydrogen, yielding the hydrogenation product quantitatively in $62 \%$ ee $(R)$ and $77 \%$ ee $(R)$, respectively. Similarly, the hydrogenation of $(Z)-\alpha$-acetamidocinnamic acid was carried out with $1 \mathrm{~mol} \%$ of the same rhodium complexes of 10 and 14 under 20 atm of hydrogen, and the hydrogenation product was obtained quantitatively in $72 \%$ ee $(S)$ and $80 \%$ ee $(S)$, respectively. In these hydrogenations, the 7-syn substituent of $\mathbf{1 0}$ has unfortunately a negative influence on the enantioselectivity of the parent ligand 14. We previously reported the correlation between the chirality of bidentate ligands and the absolute configuration of the products obtained by rhodium-catalyzed asymmetric hydrogenation or
Table 1. Asymmetric Hydrogenation of Itaconic Acid and (Z)-2-Acetamidocinnamic Acid Catalyzed by Rhodium(I) Complexes of Ligands 10, 14

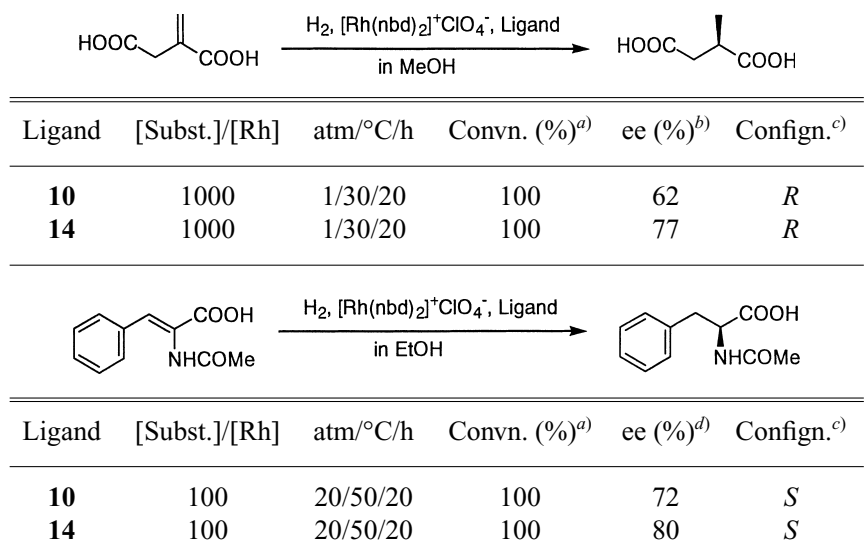

a) Determined by ${ }^{1} \mathrm{H}-\mathrm{NMR}$ analysis. b) Calculated on the basis of the specific rotation value of the pure $(R)$-enantiomer, $\left.[\alpha]_{\mathrm{D}}^{20}+16.88^{\circ}(c=2.16, \mathrm{EtOH}) . \quad c\right)$ Determined by the sign of the specific rotation. $d$ ) Calculated on the basis of the specific rotation value of the pure $(S)$-enantiomer, $[\alpha]_{\mathrm{D}}^{20}+40.1^{\circ}(c=1.0, \mathrm{MeOH})$.

palladium-catalyzed asymmetric allylic alkylation. We first proposed a $P / M$ chirality concept, ${ }^{11)}$ where the positioning array of four phenyl rings of diphosphine ligands closely cor- 


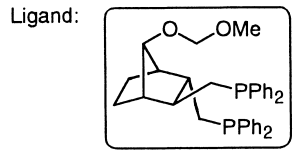

10

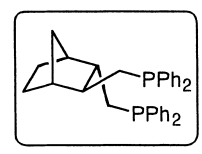

14
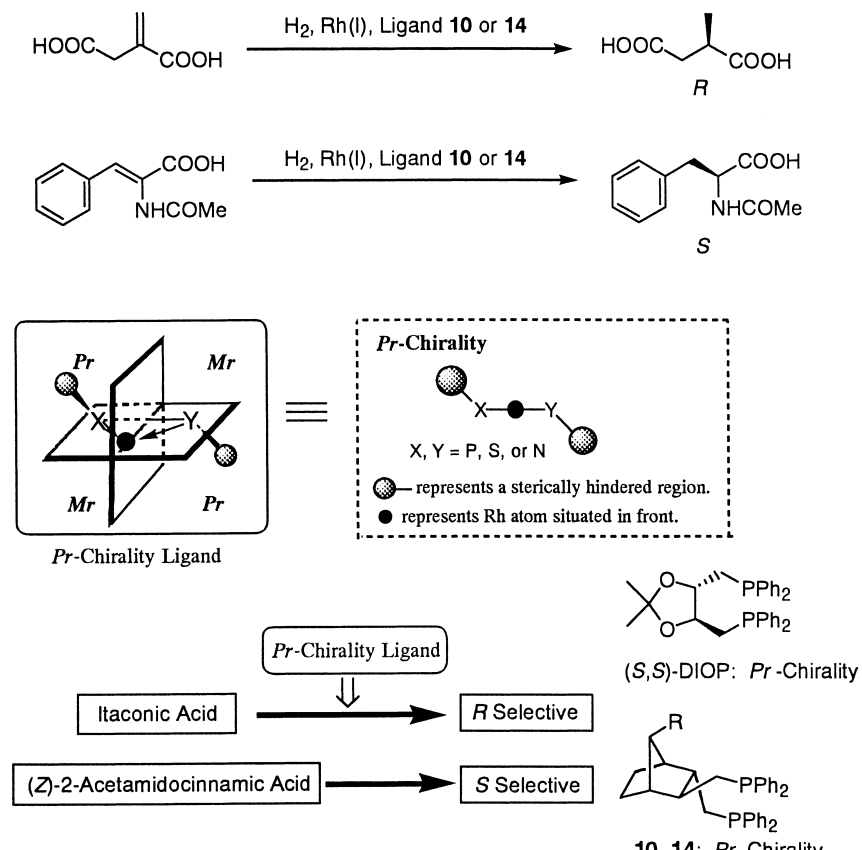

Chart 3. Correlation between the Chirality of Bidentate Ligands 10, 14 and the Absolute Configuration of the Asymmetric Hydrogenation Products

relates with the absolute configuration of products in asymmetric hydrogenation, and later represented a more general concept, $\mathrm{Pr} / \mathrm{Mr}$ chirality ${ }^{12)}$ for showing all chiral bidentate ligands (e.g, P,N-ligand, S,N-ligand, N,N-ligand, etc.) (Chart 3 ). The ligands 10, 14 showed $R$-selectivity and $S$-selectivity in the hydrogenation of itaconic acid and (Z)- $\alpha$-acetamidocinnamic acid, respectively. The $R$ - and $S$-selectivities in both hydrogenations are the same in a stereochemical sense, though the $R$ and $S$ are superficially different. (2S,3S)-2,3-OIsopropylidene-2,3-dihydroxy-1,4-bis(diphenylphosphino)butane [(S,S)-DIOP] $(\operatorname{Pr}$ chirality) bearing a similar bis(phosphinomethyl) structure showed the same enantioselectivity as $\mathbf{1 0}$ and $\mathbf{1 4}$ in both hydrogenations. ${ }^{11,13)}$ The present results on the hydrogenation with $\mathbf{1 0}$ and $\mathbf{1 4}$ also show a good correlation between the absolute configurations of the products and the chirality of the ligands ( $P r$ chirality).

In conclusion, we have described the synthesis of enantiopure norbornane diphosphine ligands bearing 7-syn-oxygen functional groups or no 7-substituent, and the results on a good correlation between the chirality of the ligands and the absolute configuration of the products in the asymmetric hydrogenation of some olefins. Further development of more efficient norbornane diphosphine ligands for asymmetric hydrogenation may be possible by introducing other heterofunctional groups into (or in place of) the 7-syn-oxygen group.

\section{Experimental}

Melting points ( $\mathrm{mp}$ ) were determined on a micro hot-stage apparatus and are uncorrected. ${ }^{1} \mathrm{H}$-NMR spectra were recorded in $\mathrm{CDCl}_{3}$ solution at $270 \mathrm{MHz}$ using a JEOL JNM-EX 270 spectrometer. Chemical shift values are expressed in ppm based on tetramethylsilane. IR spectra were measured on a JASCO IR-810 spectrometer. Optical rotations were measured on a JASCO DIP-140 digital polarimeter. Column chromatographic isolation was conducted using silica gel (Kieselgel 60, 70-230 mesh, Merck). Kieselgel 60 F254 aluminum plates (Merck) were employed for TLC. In general, all organic reagents were used as purchased. THF was distilled over sodium metal/benzophenone ketyl and used as peroxide-free. Dichloromethane and toluene were dried over Molecular Sieves 4A. Pyridine was dried by storing in the presence of sodium hydroxide. For the catalytic reactions, dehydrated methanol and ethanol were purchased and used after being degassed and filled with argon.

[1R-(2-endo,3-exo,7-anti)]-7-Trimethylsilylbicyclo[2.2.1]hept-5-ene2,3-dicarboxylic Acid Di-(1R)-menthyl Ester (3) To a stirred and chilled $\left(-78^{\circ} \mathrm{C}\right)$ solution of di- $(1 R)$-menthyl fumarate $2(12.0 \mathrm{~g}, 30.6 \mathrm{mmol})$ in toluene $(180 \mathrm{ml})$ was added dropwise a solution of diethylaluminum chloride $(0.98 \mathrm{M}$ in hexane; $31 \mathrm{ml}, 30.6 \mathrm{mmol})$. After $1 \mathrm{~h}$ stirring at $-78^{\circ} \mathrm{C}, 5$ (timethylsilyl)cyclopenta-1,3-diene $1(6.0 \mathrm{~g}, 42.8 \mathrm{mmol})$ obtained by distillation was added and the mixture was stirred for another $1 \mathrm{~h}$ at the same temperature. The reaction mixture was warmed to room temperature and saturated $\mathrm{NaHCO}_{3}$ solution $(180 \mathrm{ml})$ was added. The organic layer was extracted with isopropyl ether $(3 \times 200 \mathrm{ml})$. The combined organic layers were washed with saturated brine and dried over $\mathrm{MgSO}_{4}$. Removal of the solvents in vacuo gave $3(16.2 \mathrm{~g}, 100 \%)$ as a white solid. The diastereomeric excess was determined to be $97 \%$ de by reduction of a small portion of the product with $\mathrm{LiAlH}_{4}$ followed by ditosylation and HPLC (CHIRALCEL OD) analysis ( $97 \%$ ee). The product was purified by recrystallization from $\mathrm{EtOH}$, affording pure 3 (ca. $90 \%$ yield, $>99 \%$ de): mp $126-127^{\circ} \mathrm{C},[\alpha]_{\mathrm{D}}^{20}-9.2^{\circ}$ $\left(c=1.02, \mathrm{CHCl}_{3}\right)$. IR $(\mathrm{KBr}) \mathrm{cm}^{-1}: 1719(\mathrm{C}=\mathrm{O}) .{ }^{1} \mathrm{H}-\mathrm{NMR} \delta\left(\mathrm{CDCl}_{3}\right):-0.09$ $\left(9 \mathrm{H}, \mathrm{s}, \mathrm{Si}\left(\mathrm{CH}_{3}\right)_{3}\right), 0.75,0.74\left(3 \mathrm{H}, 3 \mathrm{H}\right.$, each d, $\left.J=2.9 \mathrm{~Hz}, \mathrm{CH}_{3} \times 2\right), 1.23(1 \mathrm{H}$, $\mathrm{s}, \mathrm{H}-7), 0.86-0.94\left(14 \mathrm{H}, \mathrm{m}, \mathrm{CH}\left(\mathrm{CH}_{3}\right)_{2} \times 2\right), 1.05-0.86,1.43,1.68,1.92$, $(2 \mathrm{H}, 4 \mathrm{H}, 4 \mathrm{H}, 4 \mathrm{H}$, each m, menthyl), $2.73(1 \mathrm{H}, \mathrm{d}, J=4.4 \mathrm{~Hz}, \mathrm{H}-3), 3.18$ (m, $1 \mathrm{H}, \mathrm{H}-4), 3.30$ (m, 1H, H-1), 3.40 (dd, $1 \mathrm{H}, J=4.4,4 \mathrm{~Hz}, \mathrm{H}-2), 4.58$ (ddd, $1 \mathrm{H}, J=4.4,11.2,11.2 \mathrm{~Hz}, \mathrm{CO}_{2} \mathrm{CH}$ ) 4.71 (ddd, $1 \mathrm{H}, J=4.4,10.8,10.8 \mathrm{~Hz}$, $\left.\mathrm{CO}_{2} \mathrm{CH}\right), 5.29(\mathrm{dd}, 1 \mathrm{H}, J=2.9,5.4 \mathrm{~Hz}, \mathrm{H}-6), 6.20(\mathrm{dd}, 1 \mathrm{H}, J=2.9,5.4 \mathrm{~Hz}, \mathrm{H}-$ 5). Anal. Calcd for $\mathrm{C}_{32} \mathrm{H}_{54} \mathrm{O}_{4} \mathrm{Si}: \mathrm{C}, 72.40 ; \mathrm{H}, 10.25$. Found: $\mathrm{C}, 72.42 ; \mathrm{H}$, 10.27 .

$\left[3 R-\left(3 \mathrm{a}, 3 \mathrm{ab}, 4 \mathrm{~b}, 5 \mathrm{a}, 6 \mathrm{~b}, 6 \mathrm{ab}, 7 R^{*}\right)\right]-6-\mathrm{Bromohexahydro-2-0x0-4-}$ (trimethylsilyl)-3,5-methano-2H-cyclopenta[b]furan-7-carboxylic Acid (1R)-Menthyl Ester (4) To an ice-cooled solution of $\mathbf{3}(6.0 \mathrm{~g}, 11.3 \mathrm{mmol})$ in dichloromethane $(30 \mathrm{ml})$ was added dropwise bromine $(1.16 \mathrm{ml}$, $22.6 \mathrm{mmol}$ ), and the mixture was stirred at room temperature for $3 \mathrm{~d}$. The reaction mixture was treated with excess sodium thiosulfate solution, washed with saturated brine, dried over $\mathrm{MgSO}_{4}$, and concentrated in vacuo. The residue was purified by silica gel column chromatography (toluene $/ \mathrm{AcOEt}=30 / 1)$, affording pure $4(5.37 \mathrm{~g}, 97.4 \%$ yield): $\mathrm{mp} 88$ $90^{\circ} \mathrm{C},[\alpha]_{\mathrm{D}}^{23}-46.7^{\circ}\left(c=1.04, \mathrm{CHCl}_{3}\right)$. IR $(\mathrm{KBr}) \mathrm{cm}^{-1}$ : 1799 (lactone $\left.\mathrm{C}=\mathrm{O}\right)$, $1725(\mathrm{C}=\mathrm{O}) .{ }^{1} \mathrm{H}-\mathrm{NMR} \delta\left(\mathrm{CDCl}_{3}\right): 0.20\left(9 \mathrm{H}, \mathrm{s}, \mathrm{Si}\left(\mathrm{CH}_{3}\right)_{3}\right), 0.74(3 \mathrm{H}, \mathrm{d}$, $\left.J=6.8 \mathrm{~Hz}, \mathrm{CHCH} \underline{C H}_{3}\right), 0.92\left(6 \mathrm{H}, \mathrm{d}, J=6.8 \mathrm{~Hz}, \mathrm{CH}\left(\mathrm{CH}_{3}\right)_{2}\right), 1.26(1 \mathrm{H}, \mathrm{s}, \mathrm{H}-7)$, $0.86-1.06,1.43,1.70,1.79,1.94(2 \mathrm{H}, 2 \mathrm{H}, 2 \mathrm{H}, 1 \mathrm{H}, 1 \mathrm{H}$, each $\mathrm{m}$, menthyl), $2.81(1 \mathrm{H}, \mathrm{d}, J=1.5 \mathrm{~Hz}, \mathrm{H}-1), 3.15(1 \mathrm{H}, \mathrm{m}, \mathrm{H}-4), 3.19(1 \mathrm{H}, \mathrm{dt}, J=1.5,4.4 \mathrm{~Hz}$, H-3), $3.29(1 \mathrm{H}, \mathrm{dd}, J=4.4 \mathrm{~Hz}, \mathrm{H}-2), 3.80(1 \mathrm{H}, \mathrm{d}, J=2.0 \mathrm{~Hz}, \mathrm{H}-5), 4.57(1 \mathrm{H}$, ddd, 4.4, 10.7, 10.7 Hz, $\left.\mathrm{CO}_{2} \mathrm{CH}\right), 4.95(1 \mathrm{H}, \mathrm{d}, J=4.9 \mathrm{~Hz}, \mathrm{H}-6)$. Anal. Calcd for $\mathrm{C}_{22} \mathrm{H}_{35} \mathrm{BrO}_{4} \mathrm{Si}: \mathrm{C}, 56.04 ; \mathrm{H}, 7.48$. Found: C, 55.89; H, 7.33.

[1R-(2-endo,3-exo,7-syn)]-7-Hydroxybicyclo[2.2.1]hept-5-ene-2,3-dicarboxylic Acid Methyl (1R)-Menthyl Ester (5) To a solution of 4 $(5.37 \mathrm{~g}, 11.0 \mathrm{mmol})$ in methanol $(250 \mathrm{ml})$ was added silver nitrate $(7.5 \mathrm{~g}$, $44.1 \mathrm{mmol}$ ), and the mixture was stirred and heated under reflux for $3 \mathrm{~d}$. After cooling to room temperature, the precipitated solid was filtered and the filtrate was concentrated in vacuo. To the residue was added water $(300 \mathrm{ml})$ and the mixture was extracted with dichloromethane $(3 \times 200 \mathrm{ml})$. The combined extracts were washed with saturated brine, dried over $\mathrm{MgSO}_{4}$, and concentrated in vacuo. The residue was purified by silica gel column chromatography (toluene/AcOEt $=4 / 1)$, affording pure 5 (3.56 g, 88\% yield): $\mathrm{mp}$ $78-81^{\circ} \mathrm{C},[\alpha]_{\mathrm{D}}^{24}+38.5^{\circ}\left(c=1.02, \mathrm{CHCl}_{3}\right)$. IR $(\mathrm{KBr}) \mathrm{cm}^{-1}: 3476(\mathrm{OH})$, $1713(\mathrm{C}=\mathrm{O}) .{ }^{1} \mathrm{H}-\mathrm{NMR} \delta\left(\mathrm{CDCl}_{3}\right): 0.74\left(3 \mathrm{H}, \mathrm{d}, J=6.8 \mathrm{~Hz}, \mathrm{CHCH}_{3}\right), 0.90$, $0.91\left(3 \mathrm{H}, 3 \mathrm{H}\right.$, each d, $\left.J=6.9,6.5 \mathrm{~Hz}, \mathrm{CH}\left(\mathrm{CH}_{3}\right)_{2}\right), 0.84-1.08,1.41,1.47$, $1.68,1.90,2.02(2 \mathrm{H}, 1 \mathrm{H}, 1 \mathrm{H}, 2 \mathrm{H}, 1 \mathrm{H}, 1 \mathrm{H}$, each m, menthyl), $2.82(1 \mathrm{H}, \mathrm{d}$, $J=4.6 \mathrm{~Hz}, \mathrm{H}-3), 3.04(1 \mathrm{H}, \mathrm{m}, \mathrm{H}-4), 3.12(1 \mathrm{H}, \mathrm{m}, \mathrm{H}-1), 3.54(1 \mathrm{H}, \mathrm{dd}, J=4.6$, $4 \mathrm{~Hz}, \mathrm{H}-2), 3.71(\mathrm{~s}, 1 \mathrm{H}, \mathrm{OH}), 3.72(1 \mathrm{H}, \mathrm{s}, \mathrm{H}-7), 3.74\left(3 \mathrm{H}, \mathrm{s}, \mathrm{CO}_{2} \mathrm{CH}_{3}\right), 4.62$ $\left(1 \mathrm{H}, \mathrm{ddd}, J=4.6,11.0,11.0 \mathrm{~Hz}, \mathrm{CO}_{2} \mathrm{CH}\right), 5.88(1 \mathrm{H}, \mathrm{dd}, J=3.2,6.4 \mathrm{~Hz}, \mathrm{H}-6)$, $6.23(1 \mathrm{H}$, dd, $J=3.7,6.4 \mathrm{~Hz}, \mathrm{H}-5)$. Anal. Calcd for $\mathrm{C}_{20} \mathrm{H}_{30} \mathrm{O}_{5}: \mathrm{C}, 68.54 ; \mathrm{H}$, 8.63. Found: C, 68.10; H, 8.82.

[1R-(2-endo,3-exo,7-syn)]-7-(Methoxymethoxy)bicyclo[2.2.1]hept-5ene-2,3-dicarboxylic Acid Methyl (1R)-Menthyl Ester (6) To a cooled solution of $5(2.96 \mathrm{~g}, 8.10 \mathrm{mmol})$ and ethyldiisopropylamine $(5.6 \mathrm{ml}$, 
$32.4 \mathrm{mmol})$ in dichloromethane $(70 \mathrm{ml})$ was added chloromethyl methyl ether $(0.62 \mathrm{ml}, 8.16 \mathrm{mmol})$. The mixture was stirred at room temperature for $3 \mathrm{~d}$. The reaction mixture was treated with saturated $\mathrm{NaHCO}_{3}(50 \mathrm{ml})$ and the organic layer was separated, washed with saturated brine, and dried over $\mathrm{MgSO}_{4}$. Removal of volatile materials in vacuo gave pure 6 (3.3 g, 99\% yield) as an oil: $[\alpha]_{\mathrm{D}}^{25}-10.7^{\circ}\left(c=1.08, \mathrm{CHCl}_{3}\right)$. IR (film) $\mathrm{cm}^{-1}: 1730$ $(\mathrm{C}=\mathrm{O}) .{ }^{1} \mathrm{H}-\mathrm{NMR} \delta\left(\mathrm{CDCl}_{3}\right): 0.90,0.91(3 \mathrm{H}, 3 \mathrm{H}$, each $\mathrm{d}, J=6.9,6.4 \mathrm{~Hz}$ $\left.\mathrm{CH}\left(\mathrm{CH}_{3}\right)_{2}\right), 0.84-1.07,1.41,1.47,1.68,1.92,2.03(2 \mathrm{H}, 1 \mathrm{H}, 1 \mathrm{H}, 2 \mathrm{H}, 1 \mathrm{H}$ $1 \mathrm{H}$, each m, menthyl), $2.84(1 \mathrm{H}, \mathrm{d}, J=4.6 \mathrm{~Hz}, \mathrm{H}-3), 3.14(1 \mathrm{H}, \mathrm{m}, \mathrm{H}-4), 3.30$ $(1 \mathrm{H}, \mathrm{m}, \mathrm{H}-1), 3.35\left(3 \mathrm{H}, \mathrm{d}, J=0.9 \mathrm{~Hz}, \mathrm{CH}_{2} \mathrm{OCH}_{3}\right), 3.64(1 \mathrm{H}, \mathrm{dd}, J=4.6,4 \mathrm{~Hz}$, $\mathrm{H}-2), 3.60(1 \mathrm{H}, \mathrm{s}, \mathrm{H}-7), 3.69\left(3 \mathrm{H}, \mathrm{s}, \mathrm{CO}_{2} \mathrm{CH}_{3}\right), 4.46(1 \mathrm{H}, \mathrm{d}, J=6.9 \mathrm{~Hz}$ $\mathrm{OCHaHbO}), 4.56(1 \mathrm{H}, \mathrm{d}, J=6.9 \mathrm{~Hz}, \mathrm{OCHaHbO}), 4.61(1 \mathrm{H}, \mathrm{ddd}, J=4.6$, $\left.11.0,11.0 \mathrm{~Hz}, \mathrm{CO}_{2} \mathrm{CH}\right), 5.90(1 \mathrm{H}, \mathrm{dd}, J=3.2,6.0 \mathrm{~Hz}, \mathrm{H}-6), 6.22$ (dd, $1 \mathrm{H}$, $J=3.7,6.0 \mathrm{~Hz}, \mathrm{H}-5)$. Anal. Calcd for $\mathrm{C}_{22} \mathrm{H}_{34} \mathrm{O}_{6}$ : C, 66.98; H, 8.69. Found: C, $67.15 ; \mathrm{H}, 8.81$.

[1R-(2-endo,3-exo,7-syn)]-7-(Methoxymethoxy)bicyclo[2.2.1]hept-5ene-2,3-dimethanol (7) To a stirred and ice-cooled solution of lithium aluminum hydride $(1.22 \mathrm{~g}, 32.2 \mathrm{mmol})$ in THF was added dropwise a solution of $6(3.3 \mathrm{~g}, 8.05 \mathrm{mmol})$ in THF $(7 \mathrm{ml})$. The mixture was stirred for $2 \mathrm{~h}$ under ice-cooling and then for $1 \mathrm{~h}$ at room temperature. The reaction mixture was cooled again with an ice-bath, and water $(5 \mathrm{ml})$ was added dropwise with caution. After stirring for $0.5 \mathrm{~h}$, the mixture was filtered through a bed of Celite, and the filter cake was extracted twice with hot THF. The filtrate and the extracts were combined, dried over $\mathrm{MgSO}_{4}$, and concentrated in vacuo. The residue was purified by silica gel column chromatography (AcOEt), affording pure $7(1.57 \mathrm{~g}, 88 \%$ yield $)$ as an oil: $[\alpha]_{\mathrm{D}}^{24}-34.4^{\circ}$ $\left(c=0.99, \mathrm{CHCl}_{3}\right)$. IR (film) $\mathrm{cm}^{-1}: 3338(\mathrm{OH}) .{ }^{1} \mathrm{H}-\mathrm{NMR} \delta\left(\mathrm{CDCl}_{3}\right): 1.14$ $1.44(1 \mathrm{H}, \mathrm{m}, \mathrm{H}-3), 2.37-2.40(1 \mathrm{H}, \mathrm{m}, \mathrm{H}-2), 2.55(1 \mathrm{H}, \mathrm{m}, \mathrm{H}-4), 2.81(1 \mathrm{H}$ $\mathrm{m}, \mathrm{H}-1), 3.30(2 \mathrm{H}, \mathrm{m}, 2 \times \mathrm{OH}), 3.21,3.70-3.76,3.89(1 \mathrm{H}, 2 \mathrm{H}, 1 \mathrm{H}, \mathrm{t}$ $\left.J=9.6 \mathrm{~Hz}, \mathrm{~m}, \mathrm{t}, J=9.6 \mathrm{~Hz}, 2 \times \mathrm{CH}_{2} \mathrm{OH}\right), 3.36\left(3 \mathrm{H}, \mathrm{s}, \mathrm{OCH}_{3}\right), 3.55(1 \mathrm{H}, \mathrm{s}, \mathrm{H}-$ 7), $4.58\left(2 \mathrm{H}, \mathrm{s}, \mathrm{OCH}_{2} \mathrm{O}\right), 5.87(1 \mathrm{H}, \mathrm{dd}, J=3.2,6.0 \mathrm{~Hz}, \mathrm{H}-6), 6.18(1 \mathrm{H}, \mathrm{dd}$ $J=3.7,6.0 \mathrm{~Hz}, \mathrm{H}-5)$. Anal. Calcd for $\mathrm{C}_{11} \mathrm{H}_{18} \mathrm{O}_{4} \cdot 2 / 5 \mathrm{H}_{2} \mathrm{O}: \mathrm{C}, 59.66 ; \mathrm{H}, 8.56$ Found: C, 59.74; H, 8.67.

[1R-(2-endo,3-exo,7-syn)]-7-(Methoxymethoxy)bicyclo[2.2.1]heptane2,3-dimethanol (8) To a solution of $7(1.54 \mathrm{~g}, 7.08 \mathrm{mmol})$ in ethano $(40 \mathrm{ml})$ was added $5 \% \mathrm{Pd}$ on carbon (containing $50 \%$ water, $0.3 \mathrm{~g}$ ), and the mixture was stirred overnight under an atmosphere of hydrogen (1 atm). After filtration of the catalyst, the filtrate was concentrated in vacuo, affording almost pure $8(1.42 \mathrm{~g}, 91 \%)$ as an oil: $[\alpha]_{\mathrm{D}}^{23}-41.8^{\circ}\left(c=1.0, \mathrm{CHCl}_{3}\right)$. IR (film) $\mathrm{cm}^{-1}: 3354(\mathrm{OH}) .{ }^{1} \mathrm{H}-\mathrm{NMR} \delta\left(\mathrm{CDCl}_{3}\right): 1.19-1.25,1.43-1.51(2 \mathrm{H}$ $2 \mathrm{H}$, each $\left.\mathrm{m}, \mathrm{CH}_{2} \mathrm{CH}_{2}\right), 1.65-1.66(1 \mathrm{H}, \mathrm{m}, \mathrm{H}-3), 1.96(1 \mathrm{H}, \mathrm{d}, J=4.1 \mathrm{~Hz}, \mathrm{H}-$ 4), 2.24 (1H, m, H-1), $2.30-2.32(1 \mathrm{H}, \mathrm{m}, \mathrm{H}-2), 3.35(2 \mathrm{H}, \mathrm{m}, 2 \times \mathrm{OH}), 3.38$ $\left(3 \mathrm{H}, \mathrm{s}, \mathrm{OCH}_{3}\right), 3.60-3.77\left(4 \mathrm{H}, \mathrm{m}, 2 \times \mathrm{CH}_{2} \mathrm{OH}\right), 3.84(1 \mathrm{H}, \mathrm{s}, \mathrm{H}-7), 4.62$ $\left(2 \mathrm{H}, \mathrm{s}, \mathrm{OCH}_{2} \mathrm{O}\right)$. Anal. Calcd for $\mathrm{C}_{11} \mathrm{H}_{20} \mathrm{O}_{4} \cdot 2 / 5 \mathrm{H}_{2} \mathrm{O}: \mathrm{C}, 59.12 ; \mathrm{H}, 9.38$ Found: C, 59.20; H, 9.45 .

[1R-(2-endo,3-exo,7-syn)]-7-(Methoxymethoxy)bicyclo[2.2.1]heptane2,3-dimethanol Dimethanesulfonate (9) To a stirred and chilled solution of $8(1.42 \mathrm{~g}, 6.47 \mathrm{mmol})$ in pyridine $(20 \mathrm{ml})$ at $-35^{\circ} \mathrm{C}$ was added a solution of methanesulfonyl chloride $(3.18 \mathrm{~g}, 27.8 \mathrm{mmol})$ in pyridine $(4 \mathrm{ml})$, and the mixture was stirred at the same temperature overnight. Water $(30 \mathrm{ml})$ was added with cooling in an ice bath and then $10 \% \mathrm{HCl}$ was added until the mixture became acidic. The mixture was extracted with AcOEt $(3 \times 50 \mathrm{ml})$, and the combined extracts were washed with water $(50 \mathrm{ml})$, saturated $\mathrm{NaHCO}_{3}(50 \mathrm{ml})$, and saturated brine $(50 \mathrm{ml})$. After being dried over $\mathrm{MgSO}_{4}$, the solvent was removed in vacuo. The residue was purified by silica gel column chromatography, affording pure $9(2.35 \mathrm{~g}, 91 \%$ yield $)$ as an oil: $[\alpha]_{\mathrm{D}}^{23}+4.02^{\circ}\left(c=1.08, \mathrm{CHCl}_{3}\right) .{ }^{1} \mathrm{H}-\mathrm{NMR} \delta\left(\mathrm{CDCl}_{3}\right): 1.15-1.21$, $1.50-1.54,1.62-1.66\left(1 \mathrm{H}, 2 \mathrm{H}, 1 \mathrm{H}\right.$, each $\left.\mathrm{m}, \mathrm{CH}_{2} \mathrm{CH}_{2}\right), 1.67-1.73(1 \mathrm{H}, \mathrm{m}$ H-3), 2.13 (1H, d, J=4.6 Hz, H-4), 2.37 (1H, m, H-1), 2.49 (1H, m, H-2), $3.02\left(3 \mathrm{H}, \mathrm{s}, \mathrm{SO}_{2} \mathrm{CH}_{3}\right), 3.05\left(3 \mathrm{H}, \mathrm{s}, \mathrm{SO}_{2} \mathrm{CH}_{3}\right), 3.05\left(3 \mathrm{H}, \mathrm{s}, \mathrm{OCH}_{3}\right), 3.95(1 \mathrm{H}$ $\mathrm{s}, \mathrm{H}-7), 4.26-4.41\left(4 \mathrm{H}, \mathrm{m}, 2 \times \mathrm{CH}_{2} \mathrm{OSO}_{2}\right), 4.62\left(2 \mathrm{H}, \mathrm{s}, \mathrm{OCH}_{2} \mathrm{O}\right)$. Anal. Calcd for $\mathrm{C}_{13} \mathrm{H}_{24} \mathrm{O}_{8} \mathrm{~S}_{2}: \mathrm{C}, 41.92 ; \mathrm{H}, 6.50$. Found: $\mathrm{C}, 41.92 ; \mathrm{H}, 6.49$.

[1R-(2-endo,3-exo,7-syn)]-[[7-(Methoxymethoxy)bicyclo[2.2.1]heptane-2,3-diyl]bis(methylene)]bis[diphenylphosphine] (10) To a chilled and stirred solution of diphenylphosphine $(5.0 \mathrm{ml}, 28.7 \mathrm{mmol})$ in THF $(50 \mathrm{ml})$ at $-40{ }^{\circ} \mathrm{C}$ was added a solution of $n$-butyllithium $(1.7 \mathrm{M}$ in hexane, $17.0 \mathrm{ml}, 28.7 \mathrm{mmol}$ ) under an argon atmosphere, and the mixture was stirred at $-35^{\circ} \mathrm{C}$ for $0.5 \mathrm{~h}$. To the THF solution of lithium diphenylphosphide formed was added dropwise a solution of $9(2.4 \mathrm{~g}, 6.4 \mathrm{mmol})$ in THF $(10 \mathrm{ml})$, and the mixture was stirred at the same temperature for $20 \mathrm{~h}$. The solvent was evaporated in vacuo and water $(100 \mathrm{ml})$ was added to the residue. The mixture was extracted with toluene $(3 \times 100 \mathrm{ml})$. The extracts were combined, dried over $\mathrm{MgSO}_{4}$, and concentrated in vacuo. The residue was purified by silica gel column chromatography (toluene/AcOEt $=20 / 1$ ), affording pure $10(2.86 \mathrm{~g}, 81 \%$ yield $):[\alpha]_{\mathrm{D}}^{25}-3.62^{\circ}\left(c=0.97, \mathrm{C}_{6} \mathrm{H}_{6}\right) .{ }^{1} \mathrm{H}-$ NMR $\delta\left(\mathrm{CDCl}_{3}\right): 0.94-1.64(6 \mathrm{H}, \mathrm{m}), 2.0-2.43(6 \mathrm{H}, \mathrm{m}), 3.17(3 \mathrm{H}, \mathrm{s}$, $\left.\mathrm{OCH}_{3}\right), 3.81(1 \mathrm{H}, \mathrm{s}, \mathrm{H}-7), 4.50\left(2 \mathrm{H}, \mathrm{dd}, J=6.3,6.3 \mathrm{~Hz}, \mathrm{OCH}_{2} \mathrm{O}\right), 7.16-7.53$ $\left(20 \mathrm{H}, \mathrm{m}, 4 \times \mathrm{C}_{6} \mathrm{H}_{5}\right)$. Anal. Calcd for $\mathrm{C}_{35} \mathrm{H}_{38} \mathrm{O}_{2} \mathrm{P}_{2}: \mathrm{C}, 76.07 ; \mathrm{H}, 6.93$. Found: C, $76.28 ; \mathrm{H}, 7.13$

[1R-(2-endo,3-exo,7-syn)]-[(7-Hydroxybicyclo[2.2.1]heptane-2,3diyl)bis(methylene)]bis[diphenylphosphine] (11) To a solution of $\mathbf{1 0}$ $(1.0 \mathrm{~g})$ in dichloromethane $(20 \mathrm{ml})$ was added trifluoroacetic acid $(10 \mathrm{ml})$ at room temperature under an argon atmosphere, and the mixture was stirred for $20 \mathrm{~h}$. The solvent and volatile materials were removed by evaporation in vacuo. To the residue was added saturated $\mathrm{NaHCO}_{3}(50 \mathrm{ml})$, and the mixture was extracted with toluene $(3 \times 30 \mathrm{ml})$. The extracts were combined, washed with saturated brine, and concentrated in vacuo. The residue was dissolved in $\mathrm{THF}$ and treated with aqueous $\mathrm{NaOH}$ for $5 \mathrm{~h}$ at room temperature under argon. After evaporation of the solvent, toluene $(100 \mathrm{ml})$ was added. The mixture was washed with water $(50 \mathrm{ml})$ and saturated brine $(50 \mathrm{ml})$, and dried over $\mathrm{MgSO}_{4}$. Evaporation of the solvent in vacuo gave almost pure 11 $(0.68 \mathrm{~g}, 74 \%$ yield $):[\alpha]_{\mathrm{D}}^{20}-17.6^{\circ}\left(c=0.98, \mathrm{C}_{6} \mathrm{H}_{6}\right) .{ }^{1} \mathrm{H}-\mathrm{NMR} \delta\left(\mathrm{CDCl}_{3}\right)$ : $0.87-1.55(7 \mathrm{H}, \mathrm{m}), 1.98-2.16(2 \mathrm{H}, \mathrm{m}), 2.35-2.45(3 \mathrm{H}, \mathrm{m}), 4.06(1 \mathrm{H}, \mathrm{s}$, $\mathrm{H}-7)$, 7.14-7.51 $\left(20 \mathrm{H}, \mathrm{m}, 4 \times \mathrm{C}_{6} \mathrm{H}_{5}\right)$. Anal. Calcd for $\mathrm{C}_{33} \mathrm{H}_{34} \mathrm{OP}_{2}: \mathrm{C}, 77.94$; $\mathrm{H}, 6.74$. Found: $\mathrm{C}, 77.92 ; \mathrm{H}, 6.94$

[1S-(2-endo,3-exo)]-Bicyclo[2.2.1]heptane-2,3-dimethanol Dimethanesulfonate (13) Dimesylate (13) was prepared from $(2 S, 3 S)$ bicyclo[2.2.1]heptane-2,3-dimethanol (12) (946 mg, $6.57 \mathrm{mmol})$ and methanesulfonyl chloride $(3.18 \mathrm{~g}, 27.8 \mathrm{mmol})$ in a similar manner as described for the synthesis of $9.13(1.85 \mathrm{~g}, 90 \%$ yield $)$ : $[\alpha]_{\mathrm{D}}^{23}+14.2^{\circ}(c=1.0$, $\left.\mathrm{CHCl}_{3}\right) .{ }^{1} \mathrm{H}-\mathrm{NMR} \delta\left(\mathrm{CDCl}_{3}\right): 1.31-1.35(1 \mathrm{H}, \mathrm{m}), 1.46-1.63(5 \mathrm{H}, \mathrm{m})$, $1.75-1.82(1 \mathrm{H}, \mathrm{m}), 2.03-2.06(1 \mathrm{H}, \mathrm{m}), 2.35(1 \mathrm{H}$, brd, $J=4.0 \mathrm{~Hz}), 2.52$ $\left(1 \mathrm{H}\right.$, br s) $3.16\left(6 \mathrm{H}, \mathrm{s}, 2 \times \mathrm{CH}_{3}\right), 4.13(1 \mathrm{H}, \mathrm{dd}, J=9.6,7.3 \mathrm{~Hz}, \mathrm{CHaHbO})$, $4.20(1 \mathrm{H}, \mathrm{dd}, J=9.6,7.3 \mathrm{~Hz}, \mathrm{CHa} \underline{\mathrm{HbO}}), 4.31(1 \mathrm{H}, \mathrm{dd}, J=9.6,7.3 \mathrm{~Hz}$, $\mathrm{CHaHbO}), 4.40(1 \mathrm{H}, \mathrm{dd}, J=9.6,7.3 \mathrm{~Hz}, \mathrm{CHaHbO})$. Anal. Calcd for $\mathrm{C}_{11} \mathrm{H}_{20} \mathrm{O}_{6} \mathrm{~S}_{2}$ : C, 42.29; H, 6.45. Found: C, 42.17; H, 6.50.

[1S-(2-endo,3-exo)]-[Bicyclo[2.2.1]heptane-2,3-diylbis(methylene)]bis [diphenylphosphine] (14) Diphosphine (14) was prepared from 13 $(1.32 \mathrm{~g}, 4.2 \mathrm{mmol})$, diphenylphosphine $(3.0 \mathrm{ml}, 16.9 \mathrm{mmol})$, and $n$-butyllithium $(1.7 \mathrm{M}$ in hexane, $10 \mathrm{ml}, 16.9 \mathrm{mmol})$ in a similar manner as described for the synthesis of 10. The product was isolated by silica gel column chromatography (hexane/toluene $=2 / 1) .14\left(1.67 \mathrm{~g}, 81 \%\right.$ yield): $[\alpha]_{\mathrm{D}}^{23}-22.4^{\circ}$ $\left(c=0.64, \mathrm{C}_{6} \mathrm{H}_{6}\right)\left[\right.$ lit. $\left.{ }^{14)}[\alpha]_{\mathrm{D}}^{22}-24.2^{\circ}\left(c=1.1, \mathrm{C}_{6} \mathrm{H}_{6}\right)\right] .{ }^{1} \mathrm{H}-\mathrm{NMR} \delta\left(\mathrm{CDCl}_{3}\right)$ : $0.99-1.59(8 \mathrm{H}, \mathrm{m}), 1.87-2.35(6 \mathrm{H}, \mathrm{m}), 7.24-7.53\left(20 \mathrm{H}, \mathrm{m}, 4 \times \mathrm{C}_{6} \mathrm{H}_{5}\right)$. FAB-MS $m / z: 493\left([\mathrm{M}+\mathrm{H}]^{+}\right)$. Anal. Calcd for $\mathrm{C}_{33} \mathrm{H}_{34} \mathrm{P}_{2}: \mathrm{C}, 80.47 ; \mathrm{H}, 6.96$. Found: C, 81.00; H, 7.19.

Catalytic Asymmetric Hydrogenation of Itaconic Acid A solution of a rhodium(I) complex catalyst was prepared in situ by mixing bis(norbornadiene)rhodium(I) perchlorate $(1.9 \mathrm{mg}, 0.005 \mathrm{mmol})$ and a chiral ligand $(0.006 \mathrm{mmol})$ in degassed methanol $(2.5 \mathrm{ml})$ was stirred at room temperature for $0.5 \mathrm{~h}$ under an argon atmosphere. To a $100-\mathrm{ml}$ round-bottomed flask were placed itaconic acid $(651 \mathrm{mg}, 5 \mathrm{mmol})$, degassed methanol $(7.5 \mathrm{ml})$, triethylamine ( $5 \mathrm{mmol})$, and a solution of the rhodium(I) complex catalyst prepared above, and the hydrogenation was carried out under hydrogen (1 atm) at $30{ }^{\circ} \mathrm{C}$ for $20 \mathrm{~h}$. After evaporation of the solvent, the residue was dissolved in aqueous $0.5 \mathrm{M} \mathrm{NaOH}$ solution $(10 \mathrm{ml})$ and extracted with dichloromethane $(10 \mathrm{ml})$. The aqueous layer was separated, acidified with $6 \mathrm{M} \mathrm{HCl}(2 \mathrm{ml})$, and extracted with ether $(3 \times 100 \mathrm{ml})$. The combined extracts were dried over $\mathrm{MgSO}_{4}$, and concentrated in vacuo. The conversion rate of the substrate was measured by ${ }^{1} \mathrm{H}-\mathrm{NMR}$ analysis, and the optical yield and the absolute configuration of the product were determined by measurement of its optical rotation value in $\mathrm{EtOH}(c=c a .2 .2)\left[\right.$ lit. $100 \%$ ee $(R):[\alpha]_{\mathrm{D}}^{20}+16.88^{\circ}(c=2.16$, EtOH)]. ${ }^{15)}$

Catalytic Asymmetric Hydrogenation of ( $Z$ )- $\alpha$-Acetamidocinnamic Acid A solution of a rhodium(I) complex catalyst was prepared in situ by mixing bis(norbornadiene)rhodium(I) perchlorate $(3.9 \mathrm{mg}, 0.01 \mathrm{mmol})$ and a chiral ligand $(0.012 \mathrm{mmol})$ in degassed ethanol $(2 \mathrm{ml})$ at room temperature for $0.5 \mathrm{~h}$ under an argon atmosphere. In a glass tube containing a magnetic stirring bar were placed a solution of $(Z)$ - $\alpha$-acetamidocinnamic acid $(205 \mathrm{mg}, 1 \mathrm{mmol})$ and triethylamine $(0.5 \mathrm{mmol})$ in degassed ethanol $(6 \mathrm{ml})$ and a solution of the rhodium(I) complex catalyst prepared above. The glass tube was placed in a stainless autoclave, and after ventilation with hydrogen ( 3 times) the pressure of hydrogen in the autoclave was adjusted at $20 \mathrm{~atm}$. The mixture was stirred and heated at $50{ }^{\circ} \mathrm{C}$ for $20 \mathrm{~h}$. After cooling to room temperature, the reaction solution was treated with active charcoal $(0.5 \mathrm{~g})$ by stirring for $0.5 \mathrm{~h}$. Filtration and concentration in vacuo gave the corresponding hydrogenation product in a quantitative yield. The conversion rate of the substrate was measured by ${ }^{1} \mathrm{H}-\mathrm{NMR}$ analysis, and the optical yield and the 
absolute configuration of the product were determined by measurement of its optical rotation value in $\mathrm{MeOH}\left(c=c a\right.$. 1.0) [lit. $100 \%$ ee $(S)$ : $[\alpha]_{\mathrm{D}}^{20}$ $+40.1^{\circ}(c=1.0 \mathrm{MeOH})$. $\left.^{16}\right)$

\section{References}

1) Seyden-Penne J., "Chiral Auxiliaries and Asymmetric Synthesis," John Wiley \& Sons, Inc., New York, 1995.

2) Brunner H., "Topics in Stereochemistry," Vol. 18, eds. by Eliel E. L., Wilen S. H., John Wiley \& Sons, New York, 1988, pp. 129-247.

3) Brown J. M., "Comprehensive Asymmetric Catalysis," Vol. 1, eds. by Jacobsen E. N., Pfaltz A., Yamamoto H., Springer, Berlin, 1999, pp. $121-182$.

4) Noyori R., Angew. Chem., Int. Ed., 41, 2008-2022 (2002).

5) Knowles W. S., Angew. Chem., Int. Ed., 41, 1998-2007 (2002).

6) Alexakis A., Benhaim C., Eur. J. Org. Chem., 2002, 3221-3236.

7) Yamazaki A., Morimoto T., Achiwa K., Tetrahedron: Asymmetry, 4, 2287-2290 (1993).
8) Furuta K., Iwanaga K., Yamamoto H., Tetrahedron Lett., 27, 45074510 (1986).

9) Fleming I., Michael J. P., J. Chem. Soc., Chem. Commun., 1978, 245247.

10) Fleming I., Michael J. P., J. Chem. Soc., Perkin Trans. 1, 1981, 15491556.

11) Sakuraba S., Morimoto T., Achiwa K., Tetrahedron: Asymmetry, 2, 597-600 (1991).

12) Saitoh A., Achiwa K., Tanaka K., Morimoto T., J. Org. Chem., 65, 4227-4240 (2000).

13) Morimoto T., Chiba M., Achiwa K., Tetrahedron Lett., 30, 735-738 (1989).

14) Aviron-Violet P., Colleuille Y., Varagnat J., J. Mol. Catal., 5, 41-50 (1979).

15) Berner E., Leonardsen R., Ann. Chem., 538, 1 (1939).

16) Vineyard B. D., Knowles W. S., Sabacky M. J., Bachman G. L., Weinkauff D. J., J. Am. Chem. Soc., 99, 5946-5952 (1977). 